\title{
Analisis dinamik model SVEIR pada penyebaran penyakit campak
}

Sitty Oriza Sativa Putri Ahaya, Emli Rahmi, and Nurwan

To cite this article:

S. O. S. P. Ahaya, E. Rahmi, and Nurwan, "Analisis dinamik model SVEIR pada penyebaran penyakit campak", Jambura J. Biomath, vol. 1, no. 2, pp. 57-64, 2020

DOI: https://doi.org/10.34312/jjbm.v1i2.8482

(C) 2020 Author(s)

\section{Articles You may be interested in}

A stage-structure Rosenzweig-MacArthur model with effect of prey refuge

L. K. Beay and M. Saija

http://dx.doi.org/10.34312/jjbm.v1i1.6891

Analisis kestabilan model predator-prey dengan infeksi penyakit pada prey dan pemanenan proporsional pada predator

S. Maisaroh, Resmawan, and E. Rahmi

http://dx.doi.org/10.34312/jjbm.v1i1.5948

Bifurkasi Hopf pada model Lotka-Volterra orde-fraksional dengan Efek Allee aditif pada predator

H. S. Panigoro and D. Savitri

http://dx.doi.org/10.34312/jjbm.v1i1.6908

Parameters estimation of generalized Richards model for COVID-19 cases in Indonesia using genetic algorithm

M. Rayungsari, M. Aufin, and N. Imamah

http://dx.doi.org/10.34312/jjbm.v1i1.6910

Global stability of a fractional-order logistic growth model with infectious disease

H. S. Panigoro and E. Rahmi

https://doi.org/10.34312/jjbm.v1i2.8135 


\title{
Analisis dinamik model SVEIR pada penyebaran penyakit campak
}

\author{
Sitty Oriza Sativa Putri Ahaya ${ }^{1}$, Emli Rahmi ${ }^{1, *}$, Nurwan ${ }^{1}$ \\ ${ }^{1}$ Jurusan Matematika, Universitas Negeri Gorontalo, Gorontalo 96128, Indonesia \\ *Penulis Korespondensi. Email: emlirahmi@ung.ac.id
}

\begin{abstract}
Abstrak
Artikel ini mengkaji dinamika model penyebaran penyakit campak dengan adanya vaksinasi menggunakan model SVEIR. Model ini membagi total populasi menjadi lima kompartemen, yaitu Susceptible (populasi rentan terhadap penyakit campak), Vaccinated (populasi rentan yang telah divaksin lanjut), Exposed (populasi dalam periode laten), Infected (populasi yang terinfeksi penyakit campak), dan Recovered (populasi yang sembuh dari penyakit campak). Pertama, titik ekuilibrium model yang terdiri atas titik bebas penyakit campak dan titik endemik penyakit campak ditentukan secara analitik. Selanjutnya, dipelajari kestabilan lokal titik ekuilibrium tersebut berdasarkan bilangan reproduksi dasar $\left(R_{0}\right)$ yang diperoleh dengan matriks generasi selanjutnya. Dari hasil analisis diperoleh bahwa titik bebas penyakit stabil asimtotik lokal jika $R_{0}<1$ dan titik endemik penyakit campak stabil asimtotik lokal jika $R_{0}>1$. Keberadaan bifurkasi maju yang diakibatkan oleh parameter laju infeksi $(\alpha)$ atau proporsi individu yang divaksin $(\theta)$ juga diberikan untuk mengetahui pengaruh perubahan parameter terhadap dinamika model. Terakhir, simulasi numerik diberikan untuk mendukung hasil analitik yang diperoleh.
\end{abstract}

Kata Kunci: Model Matematika; Campak; Titik Ekuilibrium; Kestabilan Lokal; Vaksinasi

\begin{abstract}
In this article, we analyze the dynamics of measles transmission model with vaccination via an SVEIR epidemic model. The total population is divided into five compartments, namely the Susceptible, Vaccinated, Exposed, Infected, and Recovered populations. Firstly, we determine the equilibrium points and their local asymptotically stability properties presented by the basic reproduction number $\left(R_{0}\right)$. It is found that the disease free equilibrium point is locally asymptotically stable if satisfies $R_{0}<1$ and the endemic equilibrium point is locally asymptotically stable when $R_{0}>1$. We also show the existence of forward bifurcation driven by some parameters that influence the basic reproduction number $\left(R_{0}\right)$ i.e., the infection rate $(\alpha)$ or proportion of vaccinated individuals $(\theta)$. Lastly, some numerical simulations are performed to support our analytical results.
\end{abstract}

Keywords: Mathematical Modeling; Measles; Equilibrium Point; Local Stability; Vaccination

\section{Pendahuluan}

Campak adalah penyakit menular yang disebabkan oleh virus dari genus Morbilivirus dan termasuk golongan virus RNA. Campak dapat menular melalui percikan air liur yang dikeluarkan penderita saat batuk dan bersin, serta kontak langsung dengan penderita [1]. Gejala campak ditandai dengan adanya demam tinggi ( $\geq$ 38C) yang disertai batuk, pilek, mata merah dan berair, serta Koplik's spot, yang muncul sekitar 10-12 hari setelah terpapar virus [2]. Pada tahun 2018, lebih dari 140.000 orang di dunia meninggal akibat campak yang sebagian besar adalah anak-anak di bawah usia 5 tahun [3]. Pemberian imunisasi campak diberikan pada bayi berusia $\geq$ 9 bulan karena bayi di bawah usia tersebut masih memiliki kekebalan tubuh bawaan dari ibunya. Virus campak cepat mati oleh sinar ultraviolet, bahan kimia, bahan asam, dan pemanasan. Oleh karena itu, penanganan awal terhadap penyakit campak dapat dilakukan setelah melalui konfirmasi laboratorium dengan melakukan pemeriksaan serologis (pengambilan darah pasien/serum darah) atau virologis (pengambilan urin pasien)[1].

Penyebaran penyakit menular dapat dimodelkan dengan model epidemiologi, baik menggunakan pendekatan deterministik maupun stokastik [4]. Pada bidang kesehatan, model epidemiologi dapat digunakan untuk mengajukan dan menguji teori, serta untuk membandingkan, merencanakan, melaksanakan, dan mengevaluasi berbagai program deteksi, pencegahan, atau pun kontrol [5].

Salah satu model dasar tentang penyebaran penyakit diajukan oleh Kermack dan McKendrick pada tahun 1927. Dalam model awalnya, Kermack dan McKendrick memperkenalkan model persamaan diferensial yang membagi populasi menjadi tiga kompartemen, yaitu kompartemen populasi terinfeksi (I), kompartemen populasi rentan 
(S), dan kompartemen populasi sembuh (R), yang dikenal dengan model Susceptible (rentan)-Infected (terinfeksi)Recovered (sembuh) (SIR) [6]. Model SIR digunakan untuk memodelkan penyakit dengan asumsi bahwa individu memiliki kekebalan permanen atau kekebalan sementara untuk jangka waktu yang sangat lama.

Model epidemik penyakit campak telah dikaji oleh beberapa peneliti dengan menggunakan model deterministik, seperti pada [7-10]. Dalam Momoh dkk. [7] digunakan model SEIR (Susceptible, Exposed, Infected, Recovered) untuk menganalisa pengaruh dilakukannya uji dan terapi campak pada masa inkubasi (Exposed) terhadap dinamika penyebaran penyakit campak. Selanjutnya Edward dkk. [8] menggunakan model SVEIR (Susceptible, Vaccinated, Exposed, Infected, Recovered) dengan memperhatikan proporsi imigran telah divaksin, proporsi populasi yang telah divaksin dua kali, dan laju efektivitas vaksin yang pertama. Hal ini dimodifikasi oleh Aldila dan Asrianti [9] dengan membedakan kompartemen populasi yang telah divaksin sekali dan kompartemen populasi yang telah divaksin dua kali, serta menambahkan pula kompartemen populasi yang melakukan karantina. Adapun Fakhruddin dkk. [10] memodifikasi model SIR dengan menambahkan kompartemen populasi terinfeksi yang dirawat di rumah sakit (Hospitalized).

Penerapan model SVEIR pada penyebaran penyakit campak seperti yang dikaji dalam artikel ini sejalan dengan upaya pemerintah untuk mengontrol, mengurangi, bahkan menghilangkan penyebaran penyakit campak pada populasi manusia, dengan melakukan pemberian vaksin campak secara massal sejak tahun 2000 [1]. Berdasarkan hal tersebut, model yang dikaji dalam artikel ini memodifikasi model yang diajukan oleh Momoh dkk. [7] dengan menambahkan kompartemen populasi yang telah divaksin (Vaccinated), serta menganalisa dinamika penyebaran penyakit campak dengan melihat pengaruh proporsi populasi rentan yang telah divaksin dan laju infeksi ketika individu rentan berinteraksi dengan individu terinfeksi.

\section{Formulasi Model}

Untuk membangun model deterministik SVEIR penyebaran penyakit campak diasumsikan beberapa hal sebagai berikut.

1. Recruitmen rate terhadap populasi rentan $(S)$ merupakan individu berusia $\geq 9$ bulan yang diasumsikan konstan sebesar $\Lambda$. Hal ini dikarenakan bayi $<9$ bulan memiliki kekebalan bawaan dari ibunya.

2. Populasi yang telah telah divaksin $(V)$ merupakan populasi rentan yang telah mendapatkan vaksin yang diasumsikan proporsional terhadap populasi rentan sebesar $\theta$ dengan $0 \leq \theta<1$, sehingga populasi rentan yang tidak mendapat vaksin sebesar $1-\theta$.

3. Individu rentan terinfeksi virus campak apabila berinteraksi dengan individu terinfeksi dengan laju infeksi sebesar $\alpha$.

4. Laju kematian alami di setiap kompartemen diasumsikan sama sebesar $\eta$.

5. Penyakit campak memiliki masa inkubasi sehingga ketika masa inkubasi berakhir individu pada kompartemen Exposed (E) akan berpindah ke kompartemen Infected (I) dengan laju sebesar $\beta$.

6. Individu pada kompartemen Exposed $(E)$ berpindah ke kompartemen Recovered $(R)$ dengan laju sebesar $\xi$ karena melakukan penanganan awal terhadap penyakit campak setelah melalui pemeriksaan serologis atau virologis.

7. Laju kesembuhan individu yang terinfeksi campak sebesar $\delta$.

8. Penyakit campak dapat menyebabkan kematian (fatal) dengan laju kematian sebesar $\zeta$.

9. Individu yang telah divaksin dan telah sembuh dari penyakit campak akan memperoleh kekebalan permanen sehingga tidak akan kembali terinfeksi lagi.

10. Dalam populasi diabaikan proses migrasi dan emigrasi.

Secara skematis penyebaran penyakit campak dengan model SVEIR disajikan dalam diagram transfer berikut.

Model matematika penyebaran penyakit campak berdasarkan diagram transfer pada Gambar 1 diberikan oleh:

$$
\begin{aligned}
& \frac{d S}{d t}=\Lambda-\alpha(1-\theta) S I-(\eta+\theta) S, \\
& \frac{d V}{d t}=\theta S-\eta V, \\
& \frac{d E}{d t}=\alpha(1-\theta) S I-(\beta+\eta+\xi) E, \\
& \frac{d I}{d t}=\beta E-(\zeta+\eta+\delta) I, \\
& \frac{d R}{d t}=\delta I+\xi E-\eta R .
\end{aligned}
$$




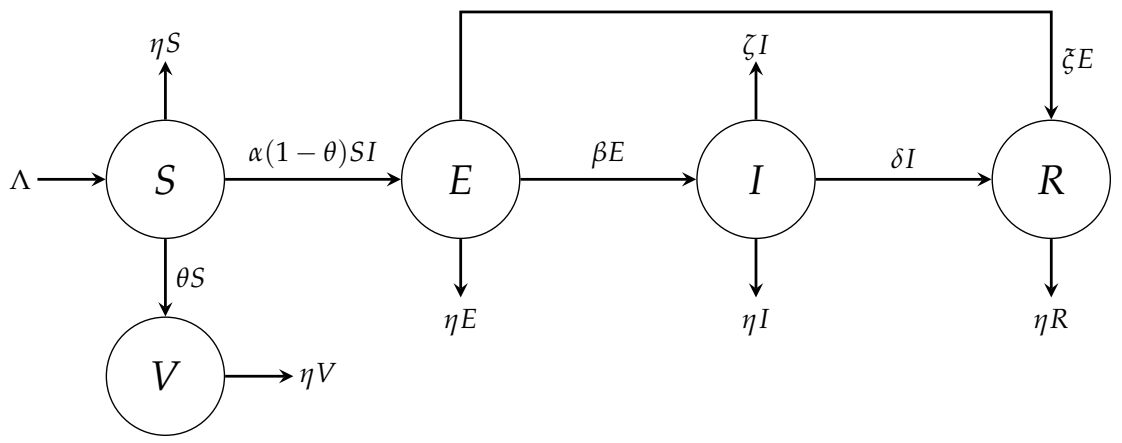

Gambar 1. Skema model SVEIR pada penyebaran penyakit campak

\section{Titik Ekuilibrium}

Titik ekuilibrium dari model (1) diperoleh dengan menyelesaikan $\frac{d S}{d t}=\frac{d V}{d t}=\frac{d E}{d t}=\frac{d I}{d t}=\frac{d R}{d t}=0$ secara simultan, sehingga diperoleh:

(a) Titik bebas penyakit campak, $P_{1}$ diberikan oleh

$$
P_{1}=\left(S^{0}, V^{0}, E^{0}, I^{0}, R^{0}\right)=\left(\frac{\Lambda}{\eta+\theta}, \frac{\Lambda \theta}{\eta(\eta+\theta)}, 0,0,0\right) .
$$

(b) Titik endemik penyakit campak, $P_{2}$ diberikan oleh

$$
P_{2}=\left(S^{*}, V^{*}, E^{*}, I^{*}, R^{*}\right)
$$

dengan

$$
\begin{aligned}
S^{*} & =\frac{\Lambda}{(\eta+\theta) R_{0}}, \\
V^{*} & =\frac{\Lambda \theta}{\eta(\eta+\theta) R_{0}}, \\
E^{*} & =\frac{\kappa_{1}\left(R_{0}-1\right)(\eta+\theta)}{\alpha \beta(1-\theta)}, \\
I^{*} & =\frac{\left(R_{0}-1\right)(\eta+\theta)}{\alpha(1-\theta)}, \\
R^{*} & =\frac{\left(\delta \beta+\xi \kappa_{1}\right)\left(R_{0}-1\right)(\eta+\theta)}{\alpha \eta \beta(1-\theta)},
\end{aligned}
$$

dengan $\kappa_{1}=\zeta+\eta+\delta, \kappa_{2}=\beta+\eta+\xi$, dan $R_{0}=\frac{\alpha \Lambda \beta(1-\theta)}{\kappa_{1} \kappa_{2}(\eta+\theta)}$ merupakan bilangan reproduksi dasar untuk model (1). Bilangan reproduksi dasar, $R_{0}$, didefinisikan sebagai jumlah infeksi baru yang dihasilkan oleh adanya satu individu terinfeksi dalam populasi, yang merupakan parameter ambang batas yang digunakan untuk memprediksi apakah suatu penyakit akan habis atau terus ada [11]. $R_{0}$ didefinisikan sebagai radius spectral atau nilai eigen terbesar dari matriks generasi selanjutnya $\left(F V^{-1}\right)$ dengan

$$
F=\left[\begin{array}{cc}
\frac{\alpha \Lambda(1-\theta)}{\eta+\theta} & 0 \\
0 & 0
\end{array}\right] \text { dan } V=\left[\begin{array}{cc}
0 & \kappa_{2} \\
\kappa_{1} & -\beta
\end{array}\right]
$$

Selanjutnya diberikan syarat eksistensi dan kestabilan lokal titik ekuilibrium model (1).

Definisikan $\Omega:=\left\{(S, V, E, I, R) \in \mathbb{R}_{+}^{5} \mid S \geq 0, V \geq 0, E \geq 0, I \geq 0, R \geq 0, \forall t \geq 0\right\}$ dan semua parameter yang digunakan bernilai positif. Misalkan $P_{i}=(S, V, E, I, R), i=1,2$ adalah solusi dari sistem (1), $P_{i}$ dikatakan titik ekuilibrium dari sistem (1) jika $\{S, V, E, I, R\} \in \Omega$ untuk setiap $S, E, I, R, V \in \mathbb{R}$. Hal ini berdasarkan kondisi biologis, bahwa setiap kompartemen harus bernilai tak negatif. Jelas bahwa $P_{1}$ selalu ada di $\Omega$. Selanjutnya akan diberikan teorema yang menyatakan eksistensi titik ekuilibrium $P_{2}$. 
Teorema 1. Titik endemik penyakit campak $P_{2}$ ada di $\Omega$ jika $R_{0} \geq 1$.

bukti. Dari pers. (4) dapat dilihat bahwa jika $R_{0}>1$ maka titik endemik campak $P_{2}=\left(S^{*}, V^{*}, E^{*}, I^{*}, R^{*}\right)$ memenuhi $S^{*}, V^{*}, E^{*}, I^{*}, R^{*}>0$. Apabila $R_{0}=1$, maka $P_{2}=P_{1} \in \Omega$.

\section{Kestabilan Titik Ekuilibrium}

Analisis kestabilan lokal di sekitar titik ekuilibrium ditentukan berdasarkan nilai eigen dari matriks Jacobi yang diperoleh dari metode linierisasi. Matriks Jacobi dari model (1) diberikan oleh

$$
J=\left[\begin{array}{ccccc}
-(\alpha(1-\theta) I+\eta+\theta) & 0 & 0 & -\alpha(1-\theta) S & 0 \\
\theta & -\eta & 0 & 0 & 0 \\
\alpha(1-\theta) I & 0 & -\kappa_{2} & \alpha(1-\theta) S & 0 \\
0 & 0 & \beta & -\kappa_{1} & 0 \\
0 & 0 & \xi & \delta & -\eta
\end{array}\right] .
$$

Teorema 2. Kestabilan lokal titik ekuilibrium.

(i) Jika $R_{0}<1$, maka titik bebas penyakit campak $P_{1}$ stabil asimtotik lokal.

(ii) Jika $R_{0}>1$, maka titik endemik penyakit campak $P_{2}$ stabil asimtotik lokal.

bukti. (i) Matriks Jacobi dari model (1) dihitung di $P_{1}$ diberikan oleh

$$
J\left(P_{1}\right)=\left[\begin{array}{ccccc}
-(\eta+\theta) & 0 & 0 & -\frac{\Lambda \alpha(1-\theta)}{\eta+\theta} & 0 \\
\theta & -\eta & 0 & 0 & 0 \\
0 & 0 & -\kappa_{2} & \frac{\Lambda \alpha(1-\theta)}{\eta+\theta} & 0 \\
0 & 0 & \beta & -\kappa_{1} & 0 \\
0 & 0 & \xi & \delta & -\eta
\end{array}\right]
$$

Dengan menghitung $\operatorname{det}\left[\lambda I-J\left(P_{1}\right)\right]=0$, diperoleh nilai eigen dari matriks (7) sebagai berikut.

$$
\begin{aligned}
\lambda_{1} & =-(\eta+\theta), \\
\lambda_{2,3} & =-\eta, \\
\lambda_{4} & =-\frac{\kappa_{1}+\kappa_{2}}{2}-\frac{1}{2} \sqrt{\left(\kappa_{1}-\kappa_{2}\right)^{2}+4 \kappa_{1} \kappa_{2} R_{0}} \\
\lambda_{5} & =-\frac{\kappa_{1}+\kappa_{2}}{2}+\frac{1}{2} \sqrt{\left(\kappa_{1}-\kappa_{2}\right)^{2}+4 \kappa_{1} \kappa_{2} R_{0}}
\end{aligned}
$$

Jelas bahwa $\lambda_{1,2,3,4}<0$. Hal ini berarti kestabilan titik bebas penyakit bergantung pada $\lambda_{5}$. Karena $R_{0}<1$ maka

$$
\begin{aligned}
R_{0}-1 & <0 \\
4 \kappa_{1} \kappa_{2}\left(R_{0}-1\right) & <0 \\
\left(\kappa_{1}+\kappa_{2}\right)^{2}-4 \kappa_{1} \kappa_{2}+4 \kappa_{1} \kappa_{2} R_{0} & <\left(\kappa_{1}+\kappa_{2}\right)^{2} \\
\left(\kappa_{1}-\kappa_{2}\right)^{2}+4 \kappa_{1} \kappa_{2} R_{0} & <\left(\kappa_{1}+\kappa_{2}\right)^{2} \\
-\frac{\kappa_{1}+\kappa_{2}}{2}+\frac{1}{2} \sqrt{\left(\kappa_{1}-\kappa_{2}\right)^{2}+4 \kappa_{1} \kappa_{2} R_{0}} & <0 \\
\lambda_{5} & <0 .
\end{aligned}
$$

Dengan demikian terbukti bahwa jika $R_{0}<1$ maka $P_{1}$ stabil asimtotik lokal.

(ii) Matriks Jacobi dari model (1) dihitung di $P_{2}$ diberikan oleh

$$
J\left(P_{2}\right)=\left[\begin{array}{ccccc}
-(\eta+\theta) R_{0} & 0 & 0 & -\frac{\alpha \Lambda(1-\theta)}{(\eta+\theta) R_{0}} & 0 \\
\theta & -\eta & 0 & 0 & 0 \\
(\eta+\theta)\left(R_{0}-1\right) & 0 & -\kappa_{2} & \frac{\alpha \Lambda(1-\theta)}{(\eta+\theta) R_{0}} & 0 \\
0 & 0 & \beta & -\kappa_{1} & 0 \\
0 & 0 & \xi & \delta & -\eta
\end{array}\right] .
$$




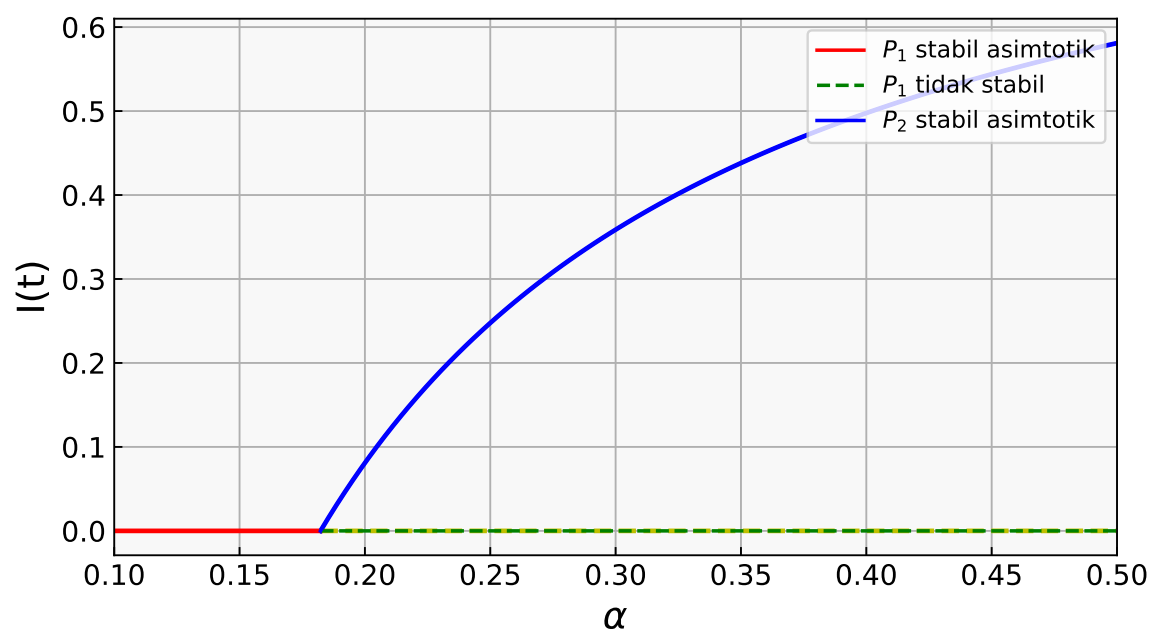

Gambar 2. Diagram bifurkasi model (1) dengan parameter bifurkasi $\alpha$ serta menggunakan nilai-nilai parameter (10) $\operatorname{dan} \theta=0.1$

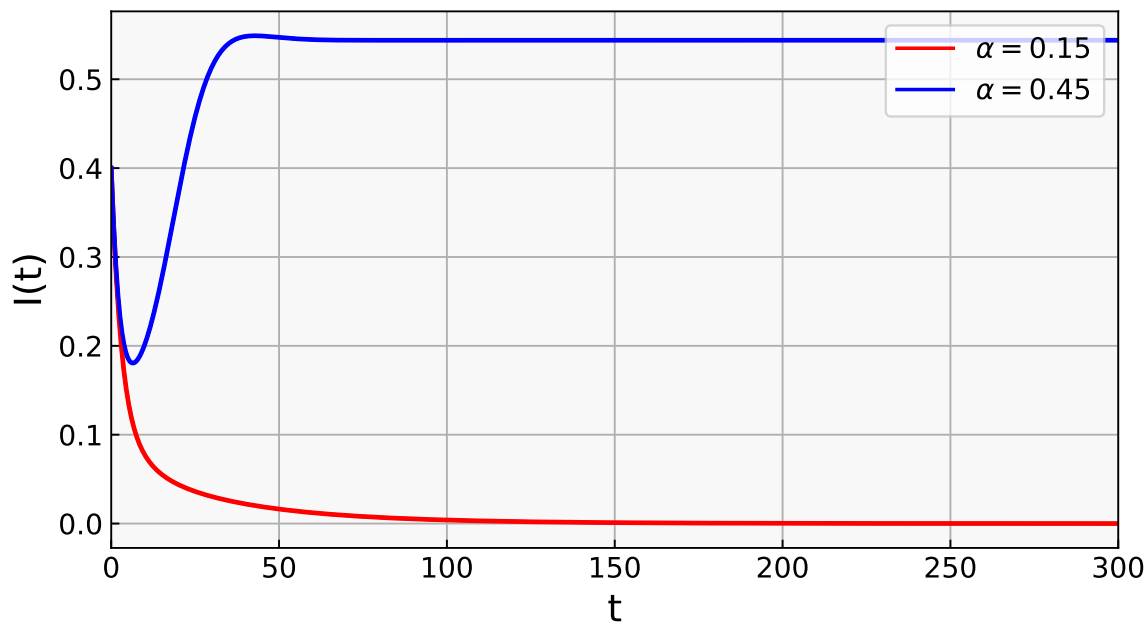

Gambar 3. Kurva deret waktu model (1) dengan nilai parameter (10) dan $\theta=0.1$

Polinom karakteristik dari $J\left(P_{2}\right)$ diberikan oleh

$$
\lambda^{5}+a_{1} \lambda^{4}+a_{2} \lambda^{3}+a_{3} \lambda^{2}+a_{4} \lambda+a_{5}=0
$$

dengan

$$
\begin{aligned}
& a_{1}=(\eta+\theta) R_{0}+2 \eta+\kappa_{1}+\kappa_{2}, \\
& a_{2}=\eta^{2}+\left(2 \eta+\kappa_{1}+\kappa_{2}\right)(\eta+\theta) R_{0}+2 \eta\left(\kappa_{1}+\kappa_{2}\right), \\
& a_{3}=\left(\kappa_{1}+\kappa_{2}\right) \eta^{2}+(\eta+\theta)\left[\eta^{2} R_{0}+2 \eta R_{0}\left(\kappa_{1}+\kappa_{2}\right)+\kappa_{1} \kappa_{2}\left(R_{0}-1\right)\right], \\
& a_{4}=\eta(\eta+\theta)\left(R_{0}\left(\kappa_{1}+\kappa_{2}\right) \eta+2 \kappa_{1} \kappa_{2}\left(R_{0}-1\right)\right), \\
& a_{5}=\kappa_{1} \kappa_{2} \eta^{2}(\eta+\theta)\left(R_{0}-1\right) .
\end{aligned}
$$

Koefisien dari polinom karakteristik (9) $a_{i}$ untuk semua $i=1,2,3,4,5$ positif, $a_{1} a_{2} a_{3}-a_{3}^{2}+a_{1}^{2} a_{4}$ positif, dan $\left(a_{1} a_{4}-a_{5}\right)\left(a_{1} a_{2} a_{3}-a_{3}^{2}-a_{1}^{2} a_{4}\right)-a_{5}\left(a_{1} a_{2}-a_{3}\right)^{2}+a_{1} a_{5}^{2}$ positif jika $R_{0}>1$. Dengan menggunakan kriteria Routh-Hurwitz untuk polinom pangkat 5 diperoleh bahwa polinom karakteristik (9) memiliki bagian riil dari nilai eigen yang bernilai negatif. Dengan demikian, titik endemik penyakit campak $P_{2}$ stabil asimtotik lokal. 


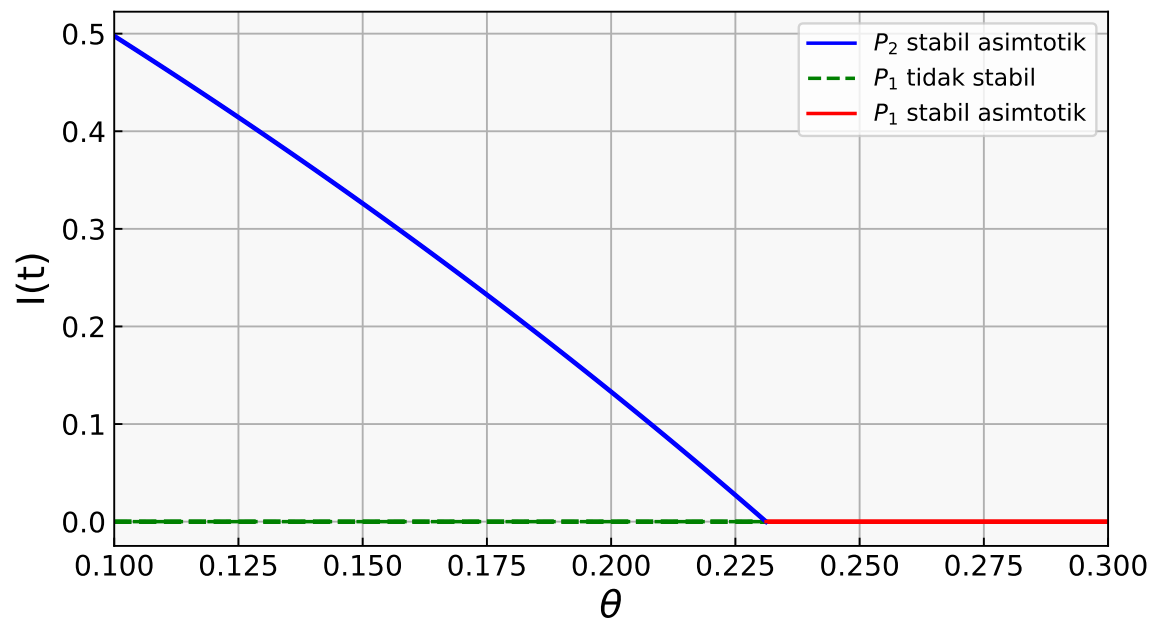

Gambar 4. Diagram bifurkasi model (1) dengan parameter bifurkasi $\theta$ serta menggunakan nilai-nilai parameter (10) dan $\alpha=0.4$

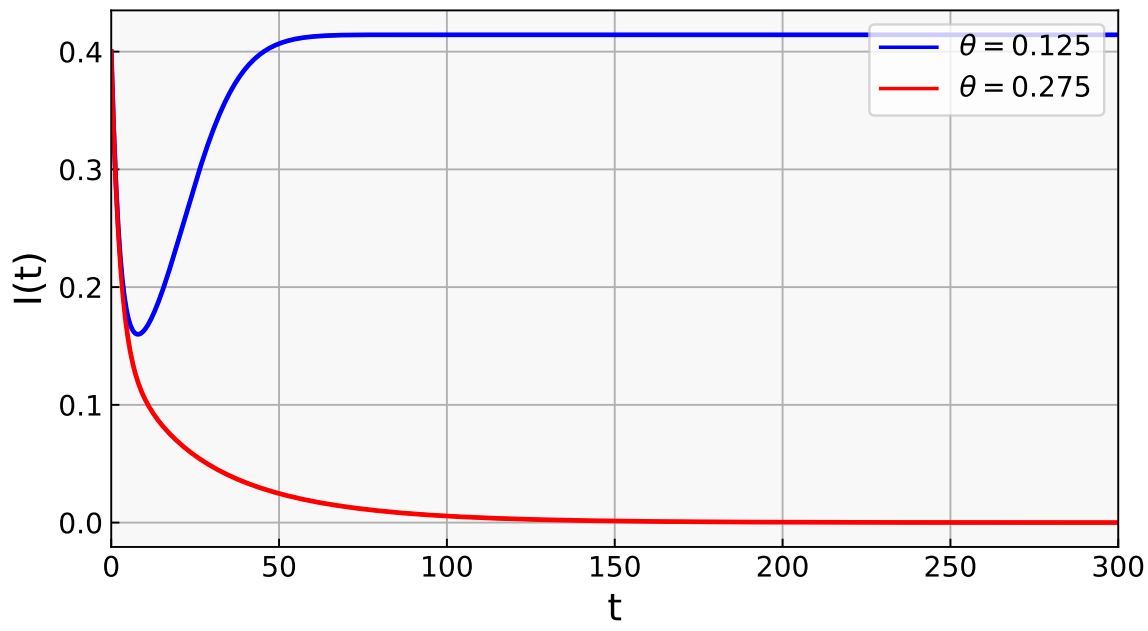

Gambar 5. Kurva deret waktu model (1) dengan nilai parameter (10) dan $\alpha=0.4$

Bilangan reproduksi dasar, $R_{0}$ sebagai fungsi dari parameter laju infeksi $(\alpha)$ atau proporsi individu yang divaksin $(\theta)$ memiliki makna penting dalam model (1). Oleh karena itu, pada artikel ini dipandang parameter $\alpha$ atau $\theta$ sebagai parameter bifurkasi.

Teorema 3. Model (1) di sekitar titik bebas penyakit campak $P_{1}$ mengalami bifurkasi maju ketika a melewati $\alpha^{*}=\frac{\kappa_{1} \kappa_{2}(\eta+\theta)}{\Lambda \beta(1-\theta)}$ atau $\theta$ melewati $\theta^{*}=\frac{\alpha \Lambda \beta-\kappa_{1} \kappa_{2} \eta}{\kappa_{1} \kappa_{2}+\alpha \Lambda \beta}$.

bukti. Ketika $\alpha<\alpha^{*}$ diperoleh $R_{0}<1$, sehingga satu-satunya titik ekuilibrium model (1) adalah titik bebas penyakit $P_{1}$ yang stabil asimtotik lokal. Namun, ketika $\alpha$ melewati titik bifurkasi $\alpha^{*}$, yaitu ketika $\alpha>\alpha^{*}$ diperoleh $R_{0}>1$ sehingga mengakibatkan $P_{1}$ kehilangan kestabilannya disertai muncul titik ekuilibrium baru $P_{2}$ yang stabil asimtotik lokal. Hal yang serupa terjadi ketika $\theta<\theta^{*}$ dalam hal ini $R_{0}>1$ maka terdapat dua titik ekuilibrium, yaitu $P_{1}$ yang tidak stabil dan $P_{2}$ yang stabil simtotik lokal. Selanjutnya ketika $\theta$ melewati titik bifurkasi $\theta^{*}$ yaitu ketika $\theta>\theta^{*}$, kedua titik ekuilibrium melebur jadi satu menghasilkan titik ekuilibrium bebas penyakit, $P_{1}$ yang stabil asimtotik lokal. Kedua fenomena ini disebut bifurkasi maju. 


\section{Simulasi Numerik}

Untuk mendukung hasil analisis yang diberikan pada bagian sebelumnya, diberikan simulasi numerik dengan menggunakan metode Runge-Kutta orde 4 [12]. Nilai-nilai parameter yang digunakan dalam simulasi disesuaikan dengan hasil analisis karena ketersediaan data yang terbatas. Adapun nilai-nilai parameter yang digunakan adalah sebagai berikut.

$$
\Lambda=0.8, \eta=0.05, \beta=0.1, \zeta=0.1, \delta=0.2, \operatorname{dan} \xi=0.1 .
$$

Dengan nilai parameter $\theta=0.1$ dan memvariasikan nilai parameter laju infeksi $\alpha$ pada interval $0.1<\alpha<0.5$ diperoleh diagram bifurkasi pada Gambar 2. Titik bebas penyakit campak $P_{1}$ yang stabil asimtotik ketika $\alpha<$ $\alpha^{*}\left(R_{0}<1\right)$ menjadi tak stabil disertai munculnya titik endemik penyakit campak $P_{2}$ ketika $\alpha>\alpha^{*}\left(R_{0}>1\right)$ dengan $\alpha^{*}=0.1822916667\left(R_{0}=1\right)$. Berdasarkan Teorema 3, fenomena ini disebut bifurkasi maju. Adapun perilaku solusi model (1) ditunjukkan oleh perilaku solusi pada kompartemen Infected (I) saja, karena solusi pada kompartemen lain akan mengikuti. Dapat dilihat bahwa ketika $\alpha=0.15$ yang berarti bahwa $R_{0}<1, P_{1}$ stabil asimtotik (kurva berwarna merah) dan ketika $\alpha=0.4$ yang berarti $R_{0}>1, P_{2}$ stabil asimtotik (kurva berwarna biru) seperti ditunjukkan pada Gambar 3. Hal ini bersesuaian dengan hasil pada Teorema 2.

Hal yang serupa terjadi bila menetapkan nilai parameter $\alpha=0.4$ dan memvariasikan nilai parameter yang menyatakan proporsi populasi rentan yang divaksin, $\theta$ pada interval $0.1<\theta<0.3$ diperoleh diagram bifurkasi pada Gambar 4. Titik bebas penyakit campak $P_{1}$ yang semula tidak stabil disertai eksisnya titik endemik penyakit campak $P_{2}$ yang stabil asimtotik ketika $\theta<\theta^{*}\left(R_{0}>1\right)$ melebur menjadi titik bebas penyakit campak $P_{1}$ yang stabil asimtotik ketika $\theta>\theta^{*}\left(R_{0}<1\right)$ dengan $\theta^{*}=0.2311715481\left(R_{0}=1\right)$. Fenomena ini berdasarkan Teorema 3 disebut bifurkasi maju. Perilaku solusi model (1) yang ditunjukkan oleh solusi pada kompartemen Infected (I) menunjukkan bahwa untuk dua nilai $\theta$ yang berbeda maka solusinya mendekati dua nilai yang berbeda. Hal ini ditunjukkan ketika $\theta=0.125$ yang berarti $R_{0}>1, P_{2}$ stabil asimtotik (kurva berwarna biru), dan ketika $\theta=0.275$ yang berarti $R_{0}<1, P_{1}$ stabil asimtotik (kurva berwarna merah) seperti pada Gambar 5 . Hal ini bersesuaian pula dengan hasil pada Teorema 2.

Berdasarkan simulasi numerik yang diberikan dapat disimpulkan bahwa parameter bifurkasi $\alpha$ dan $\theta$ dapat mempengaruhi eksistensi dan kestabilan titik ekuilibrium model (1). Ketika $R_{0}<1$ yang terjadi ketika $\alpha<\alpha^{*}$ atau $\theta>\theta^{*}$ maka dalam jangka waktu yang cukup panjang penyakit campak akan menghilang, dan ketika $R_{0}>1$ yang terjadi ketika $\alpha>\alpha^{*}$ atau $\theta<\theta^{*}$ maka dalam jangka waktu yang cukup panjang penyakit campak akan menyebar.

\section{Kesimpulan}

Model penyebaran penyakit campak dengan adanya vaksinasi telah dianalisis. Dari hasil analisis diperoleh dua titik keseimbangan, yaitu titik bebas penyakit campak yang stabil asimtotik lokal jika $R_{0}<1$ dan titik endemik penyakit campak yang eksis dan stabil asimtotik lokal jika $R_{0}>1$. Selanjutnya dapat ditunjukkan secara analitik dan numerik bahwa keberadaan bifurkasi maju yang diakibatkan oleh parameter laju infeksi $(\alpha)$ atau proporsi individu yang divaksin $(\theta)$ dapat mempengaruhi bilangan reproduksi dasar $R_{0}$ yang merupakan indikator penyebaran suatu penyakit. Berdasarkan hal tersebut, upaya penanggulangan epidemik penyakit campak dapat dilakukan dengan memperkecil laju infeksi $(\alpha)$ atau memperbesar proporsi individu yang divaksin $(\theta)$.

\section{Ucapan Terimakasih}

Ucapan terimakasih diberikan kepada kedua reviewer atas komentar dan saran yang membangun demi meningkatkan kualitas artikel ini.

\section{Referensi}

[1] Kementerian Kesehatan RI Pusat Data dan Informasi., “Situasi campak dan rubella di Indonesia," Tech. Rep., 2018.

[2] CDC, "Measles (Rubeola)," https://www.cdc.gov/measles/index.html, 2020, [Online; diakses 5 November 2020].

[3] WHO, "Measles," http://www.who.int/mediacentre/factsheets/fs286/en/index.html, 2019, [Online; diakses 5 November 2020].

[4] M. Z. Ndii, Pemodelan matematika. Yogyakarta: Penerbit Deepublish, 2018.

[5] H. W. Hethcote, “Three basic epidemiological models," Biomathematics, vol. 18, 1989.

[6] W. Kermack dan A. G. McKendrick, "A contribution to the mathematical theory of epidemics," Proceedings of the Royal Society of London, vol. Part A 115 (772), hal. 700-721, 1927. 
[7] A. A. Momoh, M. O. I. Ibrahim, I. J. Uwanta, dan S. B. Manga, "Mathematical model for control of measles epidemiology," International Journal of Pure and Applied Mathematics, vol. 67, hal. 707-718, 2013.

[8] S. Edward, K. Raymond E., K. Gabriel T., F. Nestory, M. Godfrey G., dan M. Arbogast P., "A mathematical model for control and elimination of the transmission dynamics of measles," Applied and Computational Mathematics, vol. 4, no. 6, hal. 396, 2015.

[9] D. Aldila dan D. Asrianti, "A deterministic model of measles with imperfect vaccination and quarantine intervention," Journal of Physics: Conference Series, vol. 1218, hal. 012044, 2019.

[10] M. Fakhruddin, D. Suandi, Sumiati, H. Fahlena, N. Nuraini, dan E. Soewono, “Investigation of a measles transmission with vaccination: A case study in Jakarta, Indonesia," Mathematical Biosciences and Engineering, vol. 17, no. 4, hal. 2998$3018,2020$.

[11] P. van den Driessche dan J. Watmough, "Reproduction numbers and sub-threshold endemic equilibria for compartmental models of disease transmission," Mathematical Biosciences, vol. 180, no. 1-2, hal. 29-48, 2002.

[12] A. Suryanto, Metode numerik untuk persamaan diferensial biasa dan aplikasinya dengan Matlab. Malang: Penerbit UNM, 2017.

(C) 2020 by the Authors. This article is an open access article distributed under the terms and conditions of the Creative Commons Attribution-NonComercial 4.0 International License. Editorial of JJBM: Department of Mathematics, State University of Gorontalo, Jln. Prof. Dr. Ing. B. J. Habibie, Bone Bolango 96119, Indonesia. 


\section{Submit your manuscript at http://ejurnal.ung.ac.id/}

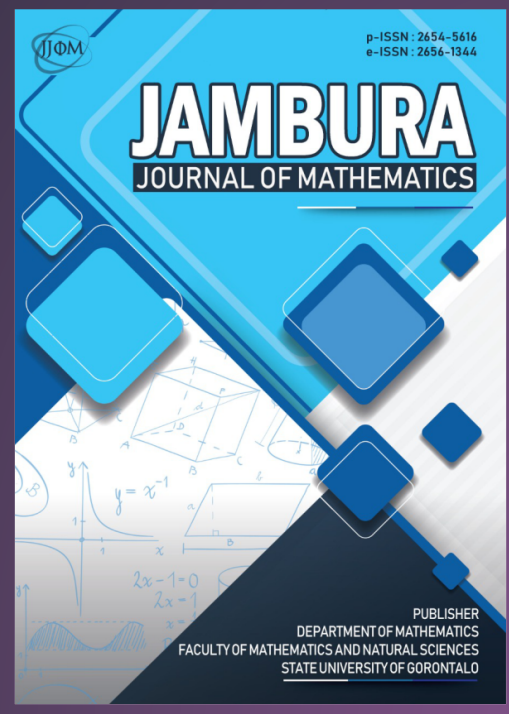

Jambura Journal of Mathematics

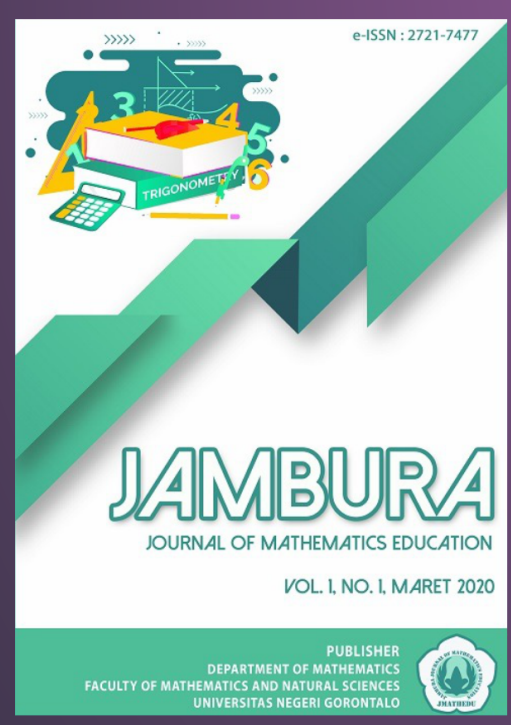

Jambura Journal of Mathematics Education
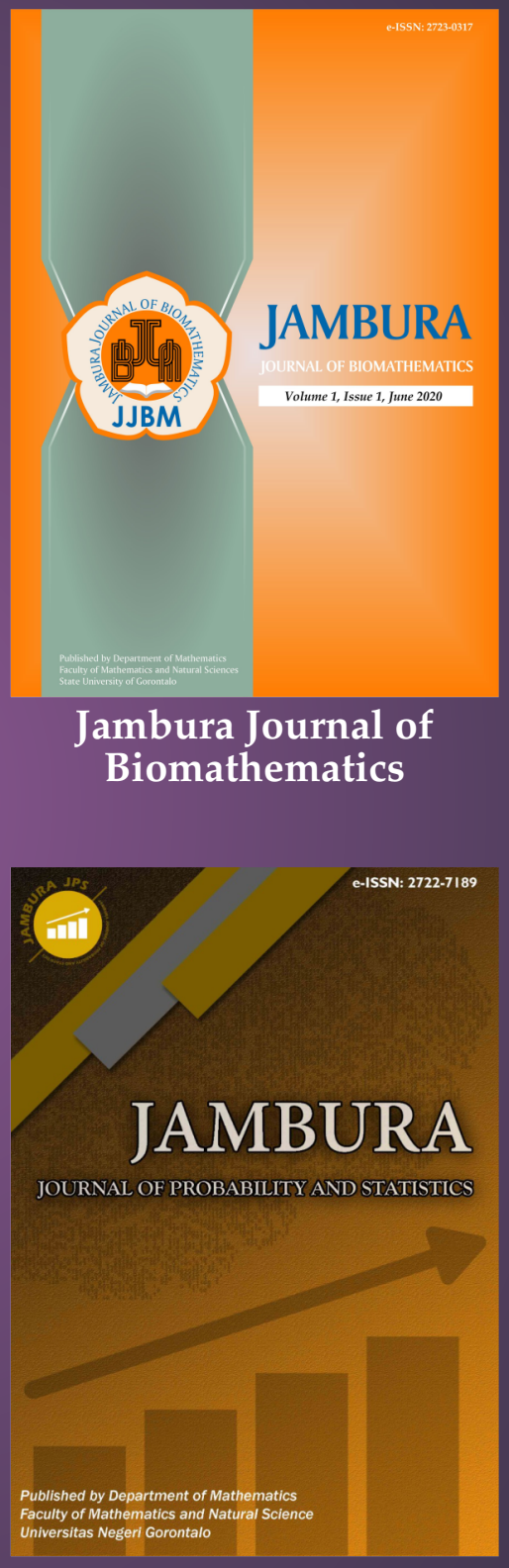

Jambura Journal of Probability and Statistics

Published by

Department of Mathematics

Faculty of Mathematics and Natural Sciences

State University of Gorontalo 